\title{
PROFIL PENALARAN ALJABAR SISWA SMA YANG MEMILIKI KECERDASAN LINGUISTIK DAN LOGIS-MATEMATIS DALAM MEMECAHKAN MASALAH MATEMATIKA
}

\author{
Ulifah Istinaro \\ Pendidikan Matematika, Fakultas Matematika dan Ilmu Pengetahuan Alam, Universitas Negeri Surabaya \\ e-mail: ulifahistinaro@mhs.unesa.ac.id \\ Rini Setianingsih \\ Pendidikan Matematika, Fakultas Matematika dan Ilmu Pengetahuan Alam, Universitas Negeri Surabaya \\ e-mail: rinisetianingsih@unesa.ac.id
}

\begin{abstract}
Abstrak
Dalam mempelajari aljabar, siswa harus memiliki kemampuan pemahaman tentang simbol aljabar dan makna persamaan dan ketidaksetaraan, yang dapat digali melalui penalaran aljabar yang memuat keterampilan mencari pola, mengenali pola, dan generalisasi pola. Salah satu cara yang dapat dilakukan guru untuk mengembangkan penalaran aljabar siswa yaitu melalui pemecahan masalah. Pemecahan masalah yang digunakan untuk mengembangkan penalaran aljabar siswa merupakan pemecahan masalah aljabar. Keterampilan penalaran aljabar dan pemecahan masalah siswa salah satunya dipengaruhi oleh kecerdasan yang dimiliki oleh siswa. Gardner mengidentifikasikan kecerdasan yang terdiri atas 8 kecerdasan, dua di antaranya yaitu kecerdasan linguistik dan logis-matematis. Tujuan penelitian ini adalah untuk mendeskripsikan profil penalaran aljabar siswa SMA yang memiliki kecerdasan linguistik dan logismatematis dalam memecahkan masalah matematika. Penelitian ini menggunakan pendekatan kualitatif. Penelitian ini dilaksanakan di kelas XI-1 SMAN 7 Surabaya tahun ajaran 2018/2019. Subjek penelitian ini terdiri dari dua siswa dengan jenis kecerdasan yang berbeda. Hasil penelitian menunjukkan bahwa setiap siswa memenuhi indikator penalaran aljabar. Siswa yang memiliki kecerdasan linguistik menuliskan jawaban dengan lengkap tetapi tidak terperinci, namun pada saat menjelaskan apa yang dituliskan pada lembar jawaban siswa tersebut menjelaskan dengan rinci menggunakan kata-katanya sendiri. Sedangkan siswa yang memiliki kecerdasan logis-matematis menuliskan jawaban dengan lengkap dan rinci, namun pada saat siswa tersebut menjelaskan apa yang dituliskan pada lembar jawaban, siswa tersebut menjelaskan dengan kata-katanya sendiri tetapi tidak terperinci.
\end{abstract}

Kata Kunci: penalaran aljabar, linguistik, logis-matematis, masalah matematika.

\begin{abstract}
In learning algebra, students must have understanding about algebraic symbols and the meaning of equality and inequality, these abilities can be explored in algebraic reasoning which includes skills in finding patterns, recognizing patterns, and generalizing patterns. One way that teachers can carry out in order to develop students' algebraic reasoning is through problem solving. Problem solving used to develop students' algebraic reasoning is algebraic problem solving. Algebraic reasoning skills and problem solving for students are influenced by the intelligence possessed by students. Gardner identifies intelligence consisting of 8 intelligences, two of which are linguistic and logical-mathematical intelligence. This study attempt to describe the algebraic reasoning profile of high school students who have linguistic intelligence and logicalmathematical intelligence in solving mathematical problems. This research uses a qualitative approach. This research was conducted in class XI-1 of SMAN 7 Surabaya in the academic year 2018/2019. The subject of this study consisted of 2 students with different types of intelligence. The results showed that each student meets algebraic reasoning indicators. Student who have linguistic intelligence write answers completely but not detailed, but when explaining what is written on the answer sheet, the student explains in detail by using her own words. While student who have logical-mathematical intelligence write answers completely and in detail, but when the student explains what is written on the answer sheet, the student explains it in her own words but not in detail.
\end{abstract}

Keywords: algebraic reasoning, linguistics, logical-mathematical, mathematical problems. 


\section{PENDAHULUAN}

Menurut Peraturan Menteri Pendidikan dan Kebudayaan No 21 tahun 2016 tentang standar isi pendidikan dasar dan menengah serta Peraturan Menteri Pendidikan dan Kebudayaan No 22 tahun 2016 tentang standar proses pendidikan dasar dan menengah dijelaskan bahwa keterampilan diperoleh melalui aktivitas-aktivitas: mengamati, menanya, mencoba, menalar, menyaji, dan mencipta. Penalaran merupakan suatu proses berpikir dalam menganalisis pola, struktur, dan keteraturan untuk menarik kesimpulan dalam memecahkan masalah.

Salah satu mata pelajaran yang membutuhkan penalaran adalah matematika. Hal ini didukung oleh pendapat dari NCTM (2000) yang menyatakan bahwa memiliki kemampuan penalaran sangat penting untuk memahami matematika. Salah satu konsep yang diajarkan dalam matematika yaitu konsep aljabar. Aljabar merupakan ilmu yang dinyatakan dengan simbol-simbol dan angka untuk menyelesaikan persamaan dan menganalisis hubungan antar kuantitas. Kemudian, Watson (2007) menyatakan bahwa pemahaman yang baik tentang hubungan antara angka, kuantitas dan relasi terkait dengan keberhasilan dalam menggunakan aljabar. Berdasarkan uraian di atas, aljabar merupakan kunci sukses dalam bidang matematika dan dalam mempelajari aljabar siswa harus memahami tentang simbol aljabar serta terbiasa menggunakan notasi aljabar. Selain itu, siswa juga harus bisa memahami arti dari variabel (lambang huruf) sebagai sesuatu yang belum diketahui serta siswa harus memahami makna persamaan dan ketidaksetaraan. Hal ini didukung oleh pendapat NCTM (2000) yang menyatakan bahwa siswa harus mengembangkan pemahaman tentang sifat aljabar yang berkaitan dengan manipulasi simbol dalam ekspresi, persamaan, dan ketidaksetaraan. NCTM (2000) juga menyatakan bahwa siswa SMA dalam mempelajari aljabar harus menganalisis dan memahami pola, hubungan dan fungsi dengan mengekspresikannya menggunakan tabel, grafik, dan simbol. Kemampuan tersebut dapat digali dalam penalaran aljabar yang memuat keterampilan mencari pola, mengenali pola dan membuat generalisasi pola.

Kaput \& Blanton (dalam Ontario Ministry of Education, 2013:2) mengungkapkan penalaran aljabar adalah sebuah proses dimana siswa menggeneralisasi ideide matematika dari serangkaian contoh-contoh khusus, menyusun generalisasi tersebut melalui argumentasi tertentu, dan menyatakannya dengan cara yang semakin formal sesuai dengan usianya. Kemudian Herbert dan Brown (2000) mengungkapkan komponen penalaran aljabar meliputi tiga aktivitas, yaitu mencari pola (pattern seeking), mengenali pola (pattern recognition), dan generalisasi (generalization). Hal ini berarti bahwa seseorang dikatakan menalar secara aljabar ketika seseorang tersebut memenuhi ketiga aktivitas dalam komponen penalaran aljabar.

Salah satu cara yang dapat dilakukan guru untuk mengembangkan penalaran aljabar siswa yaitu melalui pemecahan masalah. Hal ini didukung oleh NCTM (2000:56) yang mengungkapkan bahwa kemampuan bernalar dibutuhkan ketika siswa dituntut untuk memecahkan masalah dan mengambil kesimpulan dalam kehidupan sehari-hari. Sehingga, dalam pembelajaran matematika, siswa diharapkan mempunyai kemampuan penalaran dan pemecahan masalah. Indraswari dkk (2018) mengatakan bahwa penalaran aljabar merupakan jenis penalaran yang digunakan dalam memecahkan masalah aljabar dan pemecahan masalah juga dapat digunakan untuk mengembangkan penalaran aljabar siswa. Berikut ini indikator untuk mendeskripsikan profil penalaran aljabar yang diadaptasi dari tahap proses penalaran aljabar dalam menyelesaikan masalah matematika oleh Herbert dan Brown (2000).

Tabel 1. Indikator Penalaran Aljabar

\begin{tabular}{|c|c|}
\hline $\begin{array}{r}\text { Indikator } \\
\text { Alja }\end{array}$ & Aktivitas Pemecahan Masalah \\
\hline $\begin{array}{l}\text { Pencarian } \\
\text { (Pattern Seeking) }\end{array}$ & $\begin{array}{l}\text { a. Mengumpulkan informasi dari suatu } \\
\text { situasi dalam bentuk kata-kata, simbol, } \\
\text { atau gambar. } \\
\text { b. Merepresentasikan hal-hal yang } \\
\text { diketahui dalam bentuk gambar, } \\
\text { diagram, tabel, atau simbol. } \\
\text { c. Menemukan unsur-unsur penyusun pola. }\end{array}$ \\
\hline $\begin{array}{l}\text { Pengenalan } \\
\text { (Pattern Rec }\end{array}$ & $\begin{array}{l}\text { a. Membuat dugaan (konjektur) terkait } \\
\text { hubungan antara dua kuantitas. } \\
\text { b. Membuktikan kebenaran dugaan } \\
\text { (konjektur). }\end{array}$ \\
\hline $\begin{array}{l}\text { Generalisasi } \\
\text { (Pattern } \\
\text { Generalization) }\end{array}$ & $\begin{array}{l}\text { a. Menentukan aturan umum pola yang } \\
\text { ditemukan pada setiap unsur penyusun } \\
\text { pola. } \\
\text { b. Menentukan aturan umum persamaan } \\
\text { yang digunakan untuk memecahkan } \\
\text { masalah. }\end{array}$ \\
\hline
\end{tabular}

Setiap individu mempunyai kemampuan potensial (seperti bakat dan intelegensi) yang berbeda-beda. Oleh karena itu, dalam proses pembelajaran guru harus memperhatikan perbedaan tingkat kecerdasan dan kemampuan yang dimiliki oleh siswa. Kemampuan pemecahan masalah siswa salah satunya dipengaruhi oleh kecerdasan yang dimiliki oleh setiap siswa. Hal ini didukung oleh Gardner (2013) yang mendefinisikan kecerdasan sebagai kemampuan untuk menyelesaikan masalah, atau menciptakan produk yang berharga dalam satu atau beberapa lingkungan budaya dan masyarakat. Gardner mengidentifikasikan kecerdasan yang terdiri atas delapan kecerdasan yang dimiliki setiap individu, dua di antaranya yaitu kecerdasan linguistik dan kecerdasan logismatematis. Berdasarkan pendapat dari beberapa tokoh di 
atas, dapat dikatakan bahwa penalaran aljabar dalam memecahkan masalah matematika berhubungan dengan kecerdasan yang dimiliki setiap siswa.

Keterampilan penalaran aljabar siswa dalam memecahkan masalah matematika tidak lepas dari kemampuan pemahaman siswa akan simbol matematika dan generalisasi. Salah satu kecerdasan yang memengaruhi kemampuan siswa dalam memahami simbol-simbol matematika dan generalisasi adalah kecerdasan logismatematis. Kemampuan pemecahan masalah matematika siswa berhubungan dengan kecerdasan logis-matematis, yaitu kecerdasan yang berhubungan dengan kemampuan siswa dalam berpikir secara logis serta menggunakan angka secara efektif. Menurut Armstrong (2013) kecerdasan logis-matematis adalah kemampuan untuk menggunakan angka secara efektif dan penalaran yang baik untuk mengenali dan memecahkan masalah menggunakan pola logis untuk mengkategorikan, menyimpulkan, membuat generalisasi, dan menguji hipotesis. Hal ini juga didukung oleh pendapat Arum et al (2018) yang menyatakan bahwa kecerdasan logis-matematis siswa memainkan peran besar dalam kegiatan pemecahan masalah matematika. Lebih lanjut, hasil dari penelitian Rahbarnia, et al (2014) juga menunjukkan bahwa terdapat korelasi positif antara kecerdasan logis-matematis dan pemecahan masalah matematika.

Kemampuan siswa dalam memahami permasalahan sangat diperlukan dalam memecahkan masalah matematika. Dalam memecahkan masalah matematika, kemampuan siswa dalam memahami dan memperoleh informasi dari permasalahan dapat membantu siswa dalam memilih informasi yang dibutuhkan atau tidak dalam memecahkan masalah tersebut. Salah satu kecerdasan yang memengaruhi kemampuan siswa dalam memahami dan memperoleh informasi adalah kecerdasan linguistik. Kemampuan pemecahan masalah matematika siswa berhubungan dengan kecerdasan linguistik, yaitu kecerdasan yang berhubungan dengan kemampuan siswa dalam memahami informasi dari permasalahan yang diberikan, mengungkapkan pikiran, dan memilih informasi yang dibutuhkan dan tidak dibutuhkan dalam menyelesaikan masalah. Armstrong (2013) mendefinisikan kecerdasan linguistik sebagai kemampuan untuk menggunakan kata-kata secara efektif, baik secara lisan atau tertulis. Sehingga dapat disimpulkan bahwa penalaran aljabar siswa dalam memecahkan masalah matematika dipengaruhi oleh kecerdasan linguistik dan kecerdasan logis-matematis. Rosalina dan Ekawati (2017) menyatakan bahwa kecerdasan linguistik dapat membantu siswa dalam menyelesaikan masalah matematika yang diberikan. Oleh karena itu, dapat disimpulkan bahwa kecerdasan linguistik memiliki hubungan dengan pemecahan masalah matematika. Berdasarkan latar belakang yang telah dijabarkan di atas, maka peneliti tertarik untuk melakukan penelitian yang berjudul "Profil Penalaran Aljabar Siswa SMA yang memiliki Kecerdasan Linguistik dan LogisMatematis dalam Memecahkan Masalah Matematika."

\section{METODE}

Penelitian ini merupakan penelitian deskriptif kualitatif karena penelitian ini bertujuan untuk mendeskripsikan profil penalaran aljabar siswa SMA yang memiliki kecerdasan linguistik dan logis-matematis dalam memecahkan masalah matematika. Penelitian ini dilaksanakan di SMAN 7 Surabaya pada semester genap tahun ajaran 2018/2019. Subjek pada penelitian ini terdiri dari dua orang siswa perempuan kelas XI dengan rincian satu siswa mewakili kecerdasan linguistik dan satu siswa mewakili kecerdasan logis-matematis yang memiliki kemampuan matematika yang setara.

Instrumen penelitian yang digunakan dalam penelitian ini adalah angket kecerdasan majemuk, tes kemampuan matematika, tes penalaran aljabar, dan pedoman wawancara. Teknik pengumpulan data dalam penelitian ini menggunakan dua teknik yaitu teknik tes dan wawancara. Selanjutnya, teknik analisis data yang digunakan dalam penelitian ini yaitu kondensasi data, penyajian data, dan penarikan kesimpulan. Untuk analisis tes penalaran aljabar dalam penelitian ini berdasarkan pada indikator penalaran aljabar yang diadopsi dari Herbert \& Brown (2000) yaitu pencarian pola, pengenalan pola dan generalisasi pola.

\section{HASIL DAN PEMBAHASAN}

Pengambilan data dalam penelitian ini dilakukan di kelas XI-1 SMAN 7 Surabaya yang berjumlah 36 siswa. Dari hasil angket kecerdasan majemuk, didapatkan 1 siswa yang memiliki kecerdasan linguistik, 3 siswa yang memiliki kecerdasan logis-matematis, 3 siswa yang memiliki kecerdasan spasial, 1 siswa yang memiliki kecerdasan kinestetik, 4 siswa yang memiliki kecerdasan musikal, 13 siswa yang memiliki kecerdasan interpersonal, 3 siswa yang memiliki jenis kecerdasan intrapersonal, 3 siswa yang memiliki kecerdasan musikal dan interpersonal, 1 siswa yang memiliki kecerdasan linguistik dan interpersonal, 1 siswa yang memiliki kecerdasan kinestetik dan musikal, 1 siswa yang memiliki kecerdasan spasial dan musikal, 1 siswa yang memiliki kecerdasan spasial dan interpersonal, dan 1 siswa yang memiliki jenis kecerdasan logismatematis dan naturalis. Kemudian, hasil dari tes kemampuan matematika didapatkan 3 siswa yang memiliki kemampuan matematika yang setara pada level kemampuan matematika tinggi dengan selisih nilai tidak lebih dari 5. Berdasarkan hasil angket kecerdasan dan tes kemampuan matematika, maka diperoleh 2 siswa sebagai subjek penelitian dengan jenis kelamin yang sama pada kecerdasan linguistik dan logis-matematis. 


\section{Profil Penalaran Aljabar Subjek Lingusitik dalam Memecahkan Masalah Matematika}

Pada saat memecahkan masalah, subjek linguistik mencermati soal yang diberikan terlebih dahulu. Pada indikator pencarian pola, subjek linguistik mengumpulkan informasi dari suatu situasi yang diberikan dengan menyatakan apa yang diketahui dan apa yang ditanyakan dalam soal tersebut dengan kata-katanya sendiri berdasarkan pada pengamatan yang ia lakukan terhadap permasalahan yang diberikan. Kemudian subjek linguistik merepresentasikan hal-hal yang diketahui dalam bentuk tabel yang berisi banyaknya pohon setiap jenisnya pada setiap polanya, dengan memisalkan $\mathrm{P}=$ pohon pinus, $\mathrm{A}=$ pohon apel, dan $\mathrm{M}=$ pohon mangga. Subjek linguistik juga menjelaskan bahwa ia memisalkan ketiga jenis pohon tersebut terlebih dahulu, kemudian subjek linguistik membuat tabel yang berisi banyak masing-masing jenis pohon mulai dari pola ke-1 sampai pola ke-6. Selanjutnya subjek linguistik menemukan unsur-unsur penyusun pola yang terdapat pada setiap urutan polanya beserta alasan yang logis berdasarkan pada pengamatan yang ia lakukan pada saat mencari banyak pohon untuk setiap jenisnya pada setiap urutan polanya.

Berdasarkan uraian di atas, dapat dilihat bahwa pada indikator pencarian pola subjek linguistik menggunakan kata-katanya sendiri dalam menyatakan apa yang diketahui dan ditanyakan dan subjek linguistik memberikan alasan yang logis dalam menyatakan unsur-unsur penyusun pola. Hal ini sesuai dengan pendapat Prasetyo dan Andriani (2009) yang menyatakan bahwa kecerdasan linguistik merupakan kemampuan menggunakan bahasa untuk menyampaikan pikiran dan memahami kata-kata, baik secara lisan maupun tulisan. Hal tersebut juga sesuai dengan pendapat Prasetyo dan Andriani (2009) yang juga menyatakan bahwa seseorang yang memiliki kecerdasan linguistik salah satu cirinya yaitu mampu memahami informasi dan petunjuk/intruksi baik secara lisan maupun tulisan.

Pada indikator pengenalan pola, subjek linguistik membuat dugaan (konjektur) terkait hubungan antara dua kuantitas yaitu membuat dugaan terkait cara yang digunakan untuk menentukan banyak ketiga jenis pohon pada pola ke-n beserta alasan yang logis. Subjek linguistik menyampaikan pemikirannya dengan kata-katanya sendiri terkait cara untuk menentukan banyak masing-masing jenis pohon pada suatu pola dalam wawancara. Kemudian subjek linguistik membuktikan kebenaran dugaan (konjektur) yang telah ia buat yaitu dugaan terkait cara yang digunakan untuk menentukan banyak ketiga jenis pohon pada pola ke-n dengan menggambar pola yang ditanyakan pada soal poin a yaitu pola ke-6, kemudian mencocokkannya dengan menggunakan cara yang telah ia buat.
Berdasarkan uraian di atas, subjek linguistik dalam membuat dugaan terkait cara yang digunakan untuk menentukan banyak ketiga jenis pohon pada pola ke-n dengan menghitung banyak setiap jenis pohon mulai dari pola ke-1 sampai pola ke-4, hal ini berarti subjek linguistik mengamati banyak setiap jenis pohon mulai dari pola ke-1 sampai pola ke-4 yang mana membentuk suatu pola, kemudian subjek linguistik mencoba menjabarkan banyak setiap jenis pohon mulai dari pola ke-1 sampai pola ke-4.

Pada indikator generalisasi pola, subjek linguistik menentukan aturan umum pola yang ditemukan pada setiap unsur penyusun pola. Cara yang dibuat subjek telah terbukti kebenarannya, sehingga secara tidak langsung subjek linguistik dapat menentukan aturan umum pola yang ditemukan pada setiap unsur penyusun pola. Kemudian, subjek linguistik menentukan aturan umum persamaan yang digunakan untuk memecahkan masalah yang diberikan dalam bentuk simbol aljabar. Aturan umum persamaan biaya perawatan diperoleh dari menjumlahkan besar biaya perawatan ketiga unsur penyusun pola pada pola ke-n, karena setiap pola terdiri atas ketiga unsur tersebut. Dalam hal ini subjek linguistik menuliskan langkah-langah yang ia pakai untuk memecahkan masalah tersebut dengan lengkap tetapi tidak terperinci, namun pada saat diminta untuk menjelaskan kembali jawaban yang diperoleh, subjek linguistik menjelaskan dengan lengkap, terperinci, dan dengan kata-katanya sendiri. Hal ini sejalan dengan pendapat Yaumi dan Ibrahim (2013) yang menyatakan bahwa seseorang yang memiliki kecerdasan linguistik lebih sering menggunakan kata-kata sebagai cara utama dalam berpikir dan menyelesaikan masalah.

Profil Penalaran Aljabar Subjek Logis-matematis dalam Memecahkan Masalah Matematika

Pada saat memecahkan masalah, subjek logismatematis mencermati soal yang diberikan terlebih dahulu. Pada indikator pencarian pola, subjek logis-matematis mengumpulkan informasi dari suatu situasi yang diberikan dengan menyatakan apa yang diketahui dan apa yang ditanyakan dalam soal tersebut berdasarkan pada pengamatan yang ia lakukan terhadap permasalahan yang diberikan. Kemudian subjek logis-matematis merepresentasikan hal-hal yang diketahui dalam bentuk tabel, dengan memisalkan $\mathrm{m}=$ mangga, $\mathrm{a}=$ apel, dan $\mathrm{p}=$ pinus terlebih dahulu. Tabel yang dibuat berisi banyaknya pohon setiap jenisnya mulai dari pola ke-1 sampai pola ke6. Selanjutnya subjek logis-matematis menemukan unsurunsur penyusun polanya dengan melihat pada gambar yang ada pada soal dan berdasarkan pada pengamatan yang ia lakukan pada saat mencari banyak pohon untuk setiap jenisnya pada setiap urutan polanya beserta alasan yang logis. 
Pada indikator pencarian pola subjek logis-matematis menuliskan dan menjelaskan apa yang diketahui dan yang ditanyakan tidak menggunakan kata-katanya sendiri melainkan seperti pada soal.

Pada indikator pengenalan pola, subjek logis-matematis membuat dugaan (konjektur) terkait hubungan antara dua kuantitas yaitu membuat dugaan terkait cara yang digunakan untuk menentukan banyak ketiga jenis pohon pada pola ke-n beserta alasan yang logis. Kemudian, subjek logis-matematis membuktikan kebenaran dugaan (konjektur) yang telah ia buat yaitu dugaan terkait cara yang digunakan untuk menentukan banyak ketiga jenis pohon pada pola ke-n dengan menggambar pola yang ditanyakan pada soal poin a yaitu pola ke-6, kemudian subjek logis-matematis menghitung banyak setiap jenis pohon dan mencocokkannya dengan menggunakan cara yang telah ia buat.

Berdasarkan uraian di atas, subjek logis-matematis dalam membuat dugaan terkait cara yang digunakan untuk menentukan banyak ketiga jenis pohon pada pola ke-n dengan menghitung banyak setiap jenis pohon mulai dari pola ke-1 sampai pola ke-4, hal ini berarti subjek logismatematis mengamati banyak setiap jenis pohon mulai dari pola ke-1 sampai pola ke-4 yang mana membentuk suatu pola sehingga subjek logis-matematis menjabarkan banyak setiap jenis pohon mulai dari pola ke-1 sampai pola ke-4. Hal ini sejalan dengan pendapat dari Prasetyo dan Andriani (2009) yang menyatakan bahwa salah satu ciri seseorang yang memiliki kecerdasan logis-matematis yaitu mampu mengenali dan menguraikan pola yang abstrak atau tidak jelas.

Pada indikator generalisasi pola, subjek logismatematis menentukan aturan umum pola yang ditemukan pada setiap unsur penyusun pola. Cara yang dibuat subjek telah terbukti kebenarannya, sehingga secara tidak langsung subjek logis-matematis dapat menentukan aturan umum pola yang ditemukan pada setiap unsur penyusun pola. Subjek logis-matematis menentukan aturan umum persamaan yang digunakan untuk memecahkan masalah yang diberikan dalam bentuk simbol aljabar. Aturan umum persamaan biaya perawatan diperoleh dari menjumlahkan besar biaya perawatan ketiga unsur penyusun pola pada pola ke-n, karena setiap polanya terdapat ketiga unsur tersebut.

Selain itu, subjek logis-matematis menuliskan langkahlangkah yang ia pakai untuk memecahkan masalah tersebut dengan rinci, namun pada saat diminta untuk menjelaskan kembali jawaban yang subjek logis-matematis peroleh, subjek logis-matematis menjelaskan jawaban yang ia peroleh dengan lengkap dan dengan kata-katanya sendiri, tetapi tidak terperinci. Subjek logis-matematis dalam memecahkan masalah yang diberikan lebih menggunakan keterampilan hitung, mengenali pola dan keterampilan logika yang dimiliki. Hal ini sejalan dengan pendapat dari Armstrong (2013) yang menyatakan bahwa kecerdasan logis-matematis adalah sebuah kemampuan untuk menggunakan angka secara efektif dan penalaran yang baik untuk mengenali dan memecahkan masalah menggunakan pola logis untuk mengkategorikan, menyimpulkan, membuat generalisasi, dan menguji hipotesis. Hal tersebut juga sejalan dengan pendapat dari Prasetyo dan Andriani (2009) yang menyatakan bahwa salah satu ciri seseorang yang memiliki kecerdasan logis-matematis adalah mampu memecahkan permasalahan yang membutuhkan pemikiran logis.

\section{PENUTUP}

\section{Simpulan}

Berdasarkan penelitian yang telah dilakukan, peneliti menyimpulkan profil penalaran aljabar siswa SMA yang memiliki kecerdasan linguistik dan logis-matematis dalam memecahkan masalah matematika sebagai berikut.

1. Profil penalaran aljabar siswa SMA yang memiliki kecerdasan linguistik dalam memecahkan masalah matematika

Siswa yang memiliki kecerdasan linguistik memenuhi indikator pencarian pola, siswa mengumpulkan informasi dari suatu situasi yang diberikan dengan menyatakan apa yang diketahui dan apa yang ditanyakan dalam soal tersebut dengan katakatanya sendiri berdasarkan pada pengamatan yang siswa lakukan terhadap permasalahan yang diberikan. Kemudian siswa merepresentasikan hal-hal yang diketahui dalam bentuk tabel. Siswa menemukan unsur-unsur penyusun pola yang terdapat pada setiap urutan polanya beserta alasan yang logis berdasarkan pada pengamatan yang siswa lakukan pada saat memecahkan masalah yang diberikan.

Siswa yang memiliki kecerdasan linguistik memenuhi indikator pengenalan pola, siswa membuat dugaan (konjektur) terkait hubungan antara dua kuantitas yaitu membuat dugaan terkait cara yang digunakan untuk menentukan banyak ketiga jenis pohon pada pola ke-n beserta alasan yang logis. Siswa membuktikan kebenaran dugaan (konjektur) yang telah ia buat dengan menggambar, kemudian siswa mencocokkannya dengan menggunakan cara yang telah ia buat.

Siswa yang memiliki kecerdasan linguistik memenuhi indikator generalisasi pola, siswa menentukan aturan umum pola yang ditemukan pada setiap unsur penyusun pola. Cara yang dibuat siswa telah terbukti kebenarannya, sehingga secara tidak langsung siswa dapat menentukan aturan umum pola yang ditemukan pada setiap unsur penyusun pola. Siswa menentukan aturan umum persamaan yang 
digunakan untuk memecahkan masalah yang diberikan dalam bentuk simbol aljabar.

2. Profil penalaran aljabar siswa SMA yang memiliki kecerdasan logis-matematis dalam memecahkan masalah matematika

Siswa yang memiliki kecerdasan logismatematis memenuhi indikator pencarian pola, siswa mengumpulkan informasi dari suatu situasi yang diberikan dengan menyatakan apa yang diketahui dan apa yang ditanyakan dalam soal tersebut berdasarkan pada pengamatan yang siswa lakukan terhadap permasalahan yang diberikan. Siswa merepresentasikan hal-hal yang diketahui dalam bentuk tabel. Siswa menemukan unsur-unsur penyusun polanya dengan melihat pada gambar yang ada pada soal dan berdasarkan pada pengamatan yang siswa lakukan pada saat memecahkan masalah yang diberikan.

Siswa yang memiliki kecerdasan logismatematis memenuhi indikator pengenalan pola, siswa membuat dugaan (konjektur) terkait hubungan antara dua kuantitas yaitu membuat dugaan terkait cara yang digunakan untuk menentukan banyak ketiga jenis pohon pada pola ke-n beserta alasan yang logis. Siswa dapat membuktikan kebenaran dugaan (konjektur) yang telah ia buat, kemudian siswa menghitung banyak setiap jenis pohon dan mencocokkannya dengan menggunakan cara yang telah ia buat.

Siswa yang memiliki kecerdasan logismatematis memenuhi indikator generalisasi pola, siswa menentukan aturan umum pola yang ditemukan pada setiap unsur penyusun pola. Cara yang dibuat siswa telah terbukti kebenarannya, sehingga secara tidak langsung siswa dapat menentukan aturan umum pola yang ditemukan pada setiap unsur penyusun pola. Siswa menentukan aturan umum persamaan yang digunakan untuk memecahkan masalah yang diberikan dalam bentuk simbol aljabar.

\section{Saran}

Dalam penelitian ini masih terbatas pada penalaran aljabar siswa dalam memecahkan masalah matematika terkait materi pola dan SPLTV, sehingga kedepannya peneliti menyarankan agar melakukan penelitian serupa dalam lingkup materi yang lebih luas lagi, seperti konsep aljabar pada bangun geometri, pada fungsi komposisi, pada polinomial, dan sebagainya.

\section{DAFTAR PUSTAKA}

Armstrong, T. 2013. Kecerdasan Multiple di dalam Kelas. Terjemahan Dyah Widya Prabaningrum. Jakarta: PT. Indeks.

Arum, D. P., Kusmayadi, T. A., \& Pramudya, I. 2018. Students Logical-Mathematical Intelligence Profile. Journal of Physics: Conference Series, (Online), (https://iopscience.iop.org/article/10.1088/17426596/1008/1/012071.pdf, diakses 1 Februari 2019).

Badan Standar Nasional Pendidikan. 2016. Peraturan Menteri Pendidikan dan Kebudayaan Nomor 21 Tahun 2016 Tentang Standar Isi Pendidikan Dasar dan Menengah. Jakarta: BSNP.

Badan Standar Nasional Pendidikan. 2016. Peraturan Menteri Pendidikan dan Kebudayaan Nomor 22 Tahun 2016 Tentang Standar Proses Pendidikan Dasar dan Menengah. Jakarta: BSNP.

Gardner, H. 2013. Kecerdasan Majemuk: Teori dalam Praktik. Terjemahan Lyndon Saputra. Tangerang Selatan: Interaksara.

Herbert, K., dan Brown, H. 2000. Pattern as Tools for Algebraic Reasoning. (B. Moses, ed) Algebraic Thinking, Grade K-12 Reading from NCTMs School Based Journals and Other Publication, 123-128.

Indraswari, N. F., dkk. 2018. Algebraic Reasoning in Solving Mathematical Problem Based on Learning Style. Journal of Physics, (Online), (http://iopscience.iop.org/article/10.1088/17426596/947/1/012061/pdf, diakses 4 Oktober 2018).

NCTM. 2000. Principles and Standards for School Mathematics. Reston, VA: The National Council of Teachers of Mathematics.

Ontario Ministry of Education. 2013. Paying Attention to Algebraic Reasoning K-12. Totonto: Queen's Printer for Ontario.

Rahbarnia, F., Hamedian, S., \& Radmehr, F. 2014. A Study on the Relationship Between Multiple Intelligences and Mathematical Problem Solving based on Revised Bloom Taxonomy. Journal of Interdisciplinary Mathematics. Vol. 17(2): pp 109134.

Rosalina, A. D., dan Ekawati, R. 2017. Profil Pemecahan Masalah PISA pada Konten Change and Relationship Siswa SMP ditinjau dari Kecerdasan Linguistik, LogisMatematis, dan Visual-Spasial. Jurnal Ilmiah Pendidikan Matematika. Vol. 3(6): hal 53-62.

Suriasumantri, J. S. 2009. Filsafat Ilmu: Sebuah Pengantar Populer. Jakarta: Sinar Harapan.

Watson, A. 2007. Key Understanding in Mathematics Learning. Paper 1: Overview. Nuffield Foundation: University of Oxford. 